Indexed by

\title{
Scopus
}

\section{THE MECHANISM OF LANDSLIDE-INDUCED DEBRIS FLOW IN GEOTHERMAL AREA, BUKIT BARISAN MOUNTAINS OF SUMATRA, INDONESIA}

Crossref

KOBSON

\author{
Wahyu Wilopo \\ Universitas Gadjah Mada, \\ Department of Geological \\ Engineering, Yogyakarta, \\ Indonesia \\ Universitas Gadjah Mada, \\ Center for Disaster Mitigation \\ and Technological Innovation \\ (GAMA-InaTEK), \\ Yogyakarta, Indonesia
}

\author{
Teuku Faisal Fathani \\ Universitas Gadjah Mada, De- \\ partment of Civil and Environ- \\ mental Engineering, Yogyakar- \\ ta, Indonesia \\ Universitas Gadjah Mada, \\ Center for Disaster Mitigation \\ and Technological Innovation \\ (GAMA-InaTEK), \\ Yogyakarta, Indonesia
}

Key words: landslides, geothermal, alteration, rainfall doi:10.5937/jaes0-29741

Cite article:

Wilopo, W., Fathani, T.F. (2021) THE MECHANISM OF LANDSLIDE-INDUCED DEBRIS FLOW IN GEOTHERMAL AREA, BUKIT BARISAN MOUNTAINS OF SUMATRA, INDONESIA, Journal of Applied Engineering Science, 19(3), 688-697, DOI:10.5937/jaes0-29741 
doi: 10.5937/jaes0-29741

\title{
THE MECHANISM OF LANDSLIDE-INDUCED DEBRIS FLOW IN GEOTHERMAL AREA, BUKIT BARISAN MOUNTAINS OF SUMATRA, INDONESIA
}

\author{
Wahyu Wilopo ${ }^{1,3 *}$, Teuku Faisal Fathani2,3 \\ ${ }^{1}$ Universitas Gadjah Mada, Department of Geological Engineering, Yogyakarta, Indonesia \\ ${ }^{2}$ Universitas Gadjah Mada, Department of Civil and Environmental Engineering, Yogyakarta, Indonesia \\ ${ }^{3}$ Universitas Gadjah Mada, Center for Disaster Mitigation and Technological Innovation (GAMA-InaTEK), \\ Yogyakarta, Indonesia
}

Landslides frequently occur in Indonesia, especially in the geothermal areas located on Sumatra's mountainous island. On April 28, 2016, around 04:30 Western Indonesia Time, a landslide-induced debris flow occurred in Lebong District, Bengkulu Province, Indonesia. The source area of the landslide was located at Beriti Hill on the Bukit Barisan Mountain Range. It resulted in 6 fatalities and damage to infrastructures such as geothermal facilities, roads, water pipes, houses, and bridges. Subsequent landslides and debris flows occurred on April 30, May 2, and 3, 2016. Therefore, this study aims to examine the mechanism and to know the most significant contributing factor to the Beriti Hill landslide. Field investigation, soil sampling, XRD analysis, and Lidar analysis were carried out in the research. Beriti Hill is a geothermal area with many manifestations and is composed of volcanic rocks. Alteration processes produced a thick layer of soil from volcanic rocks. The thick soil dominated by clay minerals and steep slopes is the dominant controlling factor of a landslide, triggered by high rainfall intensity. Increasing water saturation in the landslide material due to high rainfall is the most contributing factor to the developing debris flow from the landslide. Debris flows are recurring events based on the Air Kotok river's stratigraphic data downstream of the landslide area. The debris flow material is toxic due to the low $\mathrm{pH}$ from the geothermal process. Therefore, the alluvial fan deposit area from Beriti Hill debris flow is a hazard zone and unsuitable for settlement and agriculture. This research shows that a landslide mechanism in a geothermal area was controlled by clay mineral presence due to the alteration process. The future of landslide risk assessment in the geothermal area can be considered by detailing clay type and their characteristic that significantly contributes to debris flow.

Key words: landslides, geothermal, alteration, rainfall

\section{INTRODUCTION}

A landslide is the movement of a mass of rock, earth, or debris down a slope [1]. Landslides are categorized based on the materials and their moving process [2]. The landslide materials can be divided into loess-paleosol and loess-bedrock, which for movement consists of slide, fall, topple, flow, and spall [3]. A landslide occurs due to shear failure along the landslide field, which is the boundary of soil or rock mass movement. Landslides on slopes are caused by changes in the effective stresses, variations of material properties, or geometry changes. Effective stresses can be influenced either directly due to differences in external forces (earthquake, human activity) or indirectly through water pore pressure from rainfall [4-5]. Degradation processes can cause variations in slope material properties from weathering and chemical reactions [6].

Several internal factors contributing to landslides are slopes (geomorphic), geologic, and hydrologic conditions [7]. Landslides are usually triggered by external factors such as earthquakes, heavy rainfall, or strong vibration, but sudden events can occur without any of these factors occurring [8-9]. Earth movements depend on the moving material, topography, and water content [8]. Landslides and debris flows are common phenomena in mountainous areas and are triggered by earthquakes and rainfall [10-11]. The movement of soil or rock mass on the slope can occur due to the interaction of several conditions, including morphology, geology, geological structure, hydrogeology, and land use [12]. These conditions influence each other and form slope conditions that have a tendency or potential to move. Even though the slope is already susceptible to collapse, if there is no trigger from rain, earthquake, or human activity, a landslide will not occur. Some researchers have carried out studies to understand landslide occurrence mechanism $[13,14]$. The ancient landslide in Breckenridge, Quebec, Canada is a "flake" type failure occurred in sensitive clay and triggered by earthquake [13] and the Wulipo landslide which was transformed into debris flow and occurred in the Upper Cretaceous Guankou formation with siltstone and mudstone interbedded, was triggered by heavy rainfall [14]. The current study investigated slope failure mechanism in geothermal areas to understand the triggering mechanism and also to look into the type of the minerals of the areas.

Geothermal areas are specific areas characterized by 


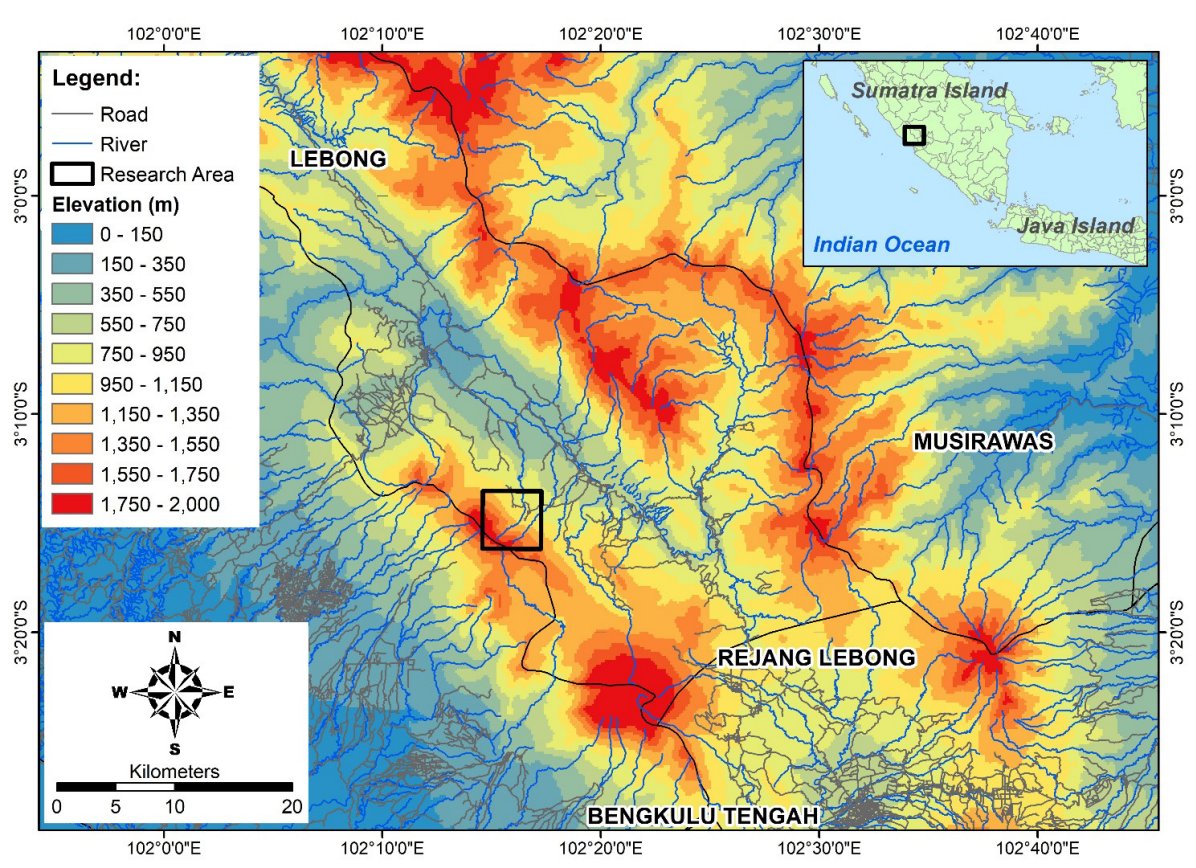

Figure 1: Landslide location at Beriti Hill in Lebong District, Bengkulu Province

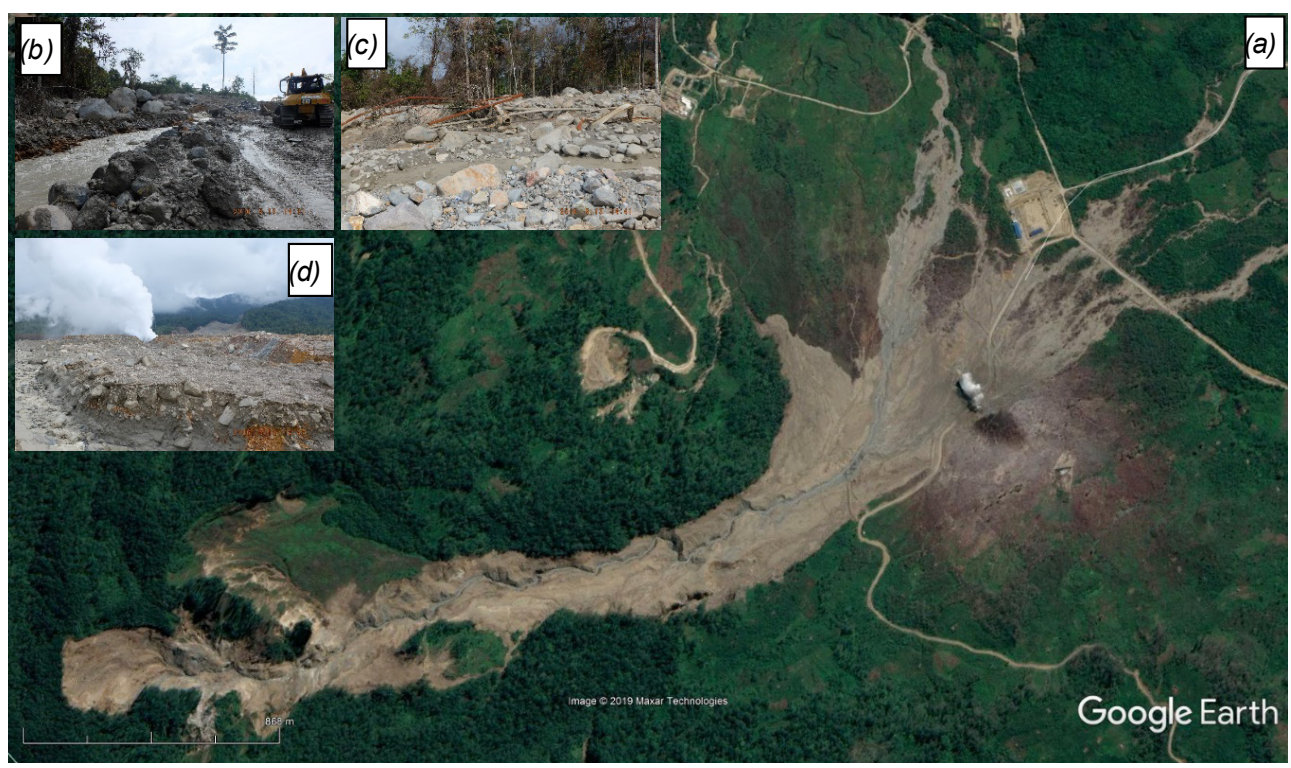

Figure 2: (a) Google Earth Image on 28-09-2016 after the landslide [19]; (b) road damage; (c) water pipe damage;

(d) geothermal wellhead damage

a very thick soil layer, and most of them are located in the mountain area. The thick soil is dominated by clay minerals from alteration products [15]. Therefore, it is very easy to collapse due to rainfall or earthquake, or a combination of both. The sliding surface's potential in the geothermal area consists of a clay layer dominated by the mineral of halloysite and metahalloysite [16]. Besides, montmorillonite clay minerals in the geothermal area also contribute to the landslide due to their swelling potential [17]. A significant landslide in the altered hydrothermal area is mostly related to argillic alteration when medium to small landslides mainly occur in prophylitic alteration [18].

Landslides frequently occur in Indonesia due to complex geology, topographic, and tectonic conditions. An island in Indonesia that often experiences landslides is Sumatra. This island is composed of the Bukit Barisan 689 mountain range that extends from northwest to southeast, forming valleys and hills. On April 28, 2016, at around 04:30 Western Indonesia Time, a landslide-induced debris flow occurred in Lebong District, Bengkulu Province, Indonesia, as shown in Figure 1. The landslide was originated from Beriti Hill. The crown of the landslide was located in Beriti Hill caldera at $3^{\circ} 15^{\prime} 11,5^{\prime \prime} \mathrm{S}$ and $102^{\circ} 14^{\prime} 40,9^{\prime \prime} \mathrm{E}$, about $2.5 \mathrm{~km}$ from a geothermal facility. It resulted in 6 fatalities and damage to infrastructures such as geothermal facilities, roads, water pipes, houses, and bridges, as shown in Figure 2. Subsequent landslides-induced debris flows occurred on April 30, May 2, and 3, 2016. This research studies the mechanism and factors that triggered landslide-induced debris flow in Beriti Hill. It also examines the geological condition in the Beriti Hill area and the impact of the debris flows. 


\section{METHODOLOGY}

The research was conducted by field investigation, soil sampling, XRD analysis, and light detection and ranging (LiDAR) analysis. A field investigation was undertaken to identify the deposited materials' rock layer and types in the sources zone, transported zone, and deposited zone. Nine soil samples were taken from the field, which each zone had three samples to identify their mineral composition using XRD from Rigaku. The soil samples were taken taken from the middle of each layer at a depth of $30-50 \mathrm{~cm}$ based on the field outcrop. The XRD analysis for soil samples was carried out with oriented clay mineral aggregates [20]. The sample was prepared by air-drying and removing organic materials with $30 \%$ $\mathrm{H}_{2} \mathrm{O}_{2}$ solution, and then it was ground to get appropriate particle size by hand grinder using agate mortar. They were then ethylene glycol (EG) solvation and heated at $550^{\circ} \mathrm{C}$ for 1 hour before detected by the XRD equipment. The position and the intensity of peaks in a diffraction pattern from the XRD result were compared to the international center for diffraction database to identify the mineral type. Besides, undisturbed soil samples were collected from the depositional zone to determine their physical and mechanical properties according to ASTM standards. The $\mathrm{pH}$ measurement was conducted both in the material and seepage water by $\mathrm{pH}$ meter from Hanna instruments. The $\mathrm{pH}$ meter was calibrated in compliance with the manual of the device before it was used in the field. The landslide material volume was calculated by comparing the topography data before and after the landslide occurrence and multiplying it with the depositional area using a geographical information system (GIS) [21]. The topography models were developed by digital elevation model (DEM) from LiDAR data. Rainfall data were collected from the nearest rain gauge of Kepahiang Meteorological Station around 10km from Beriti Hill [22] and JAXA Global Rainfall Watch [23]. Earthquake data were collected from USGS open data [24].

\section{GEOLOGY OF THE RESEARCH AREA}

Soil mass movements are mostly influenced by morphological conditions, lithology, and geological structures [25]. The landslide sources are coming from the caldera of Beriti Hill. The morphological conditions of the peak of Beriti Hill indicate a volcanic caldera shaped like a bowl with a narrow gap in the northeast as the headstream of the Air Kotok River, as shown in Figure 3. The caldera has a steep slope of more than $40^{\circ}$. The morphology can be divided into three zones, i.e.: (1) the source area of a caldera in the high slope zone; (2) the transport area in the moderate slope zone, which then progresses downstream into the low slope zone; and (3) the depositional area in the slope zone, which has a relatively flat slope, as shown in Figure 3.

Figure 2(a) shows alluvial fans deposit from landslide materials. Alluvial fans are the accumulated sediment that

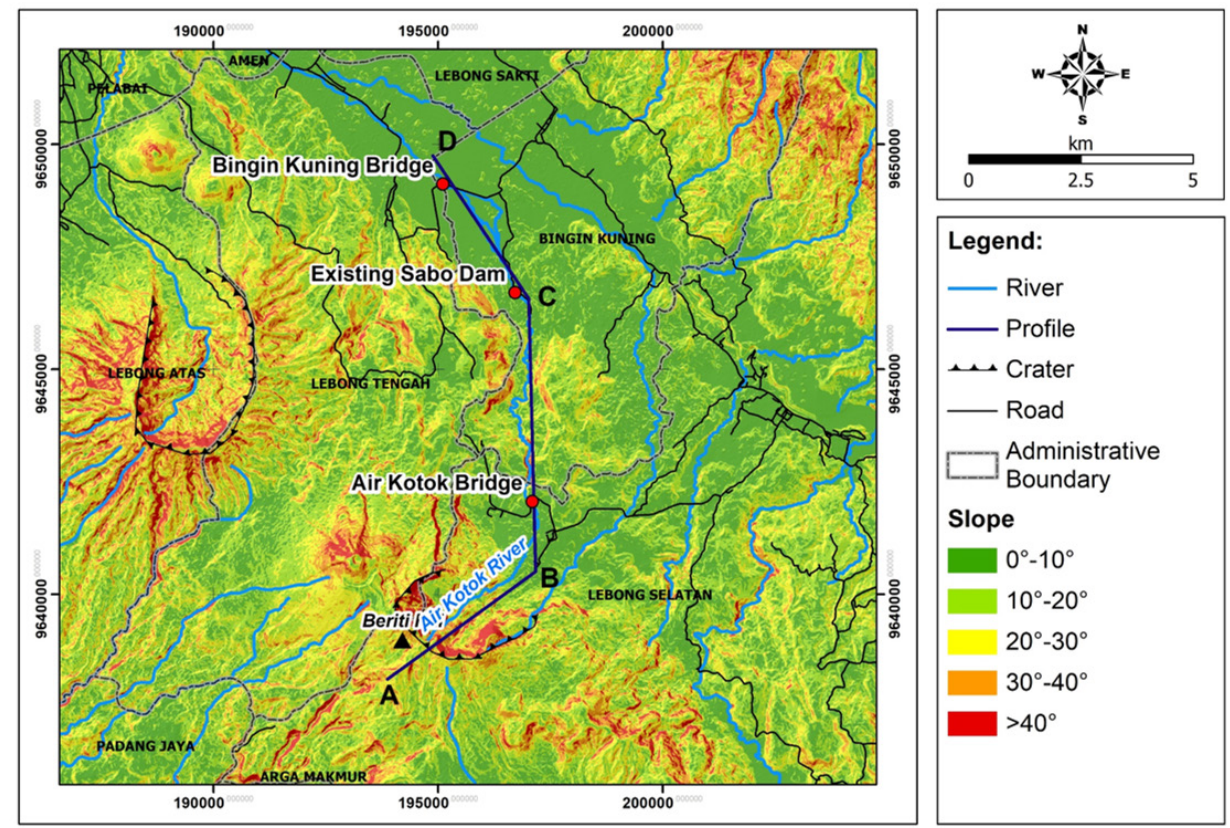

GEOMORPHOLOGICAL PROFILE

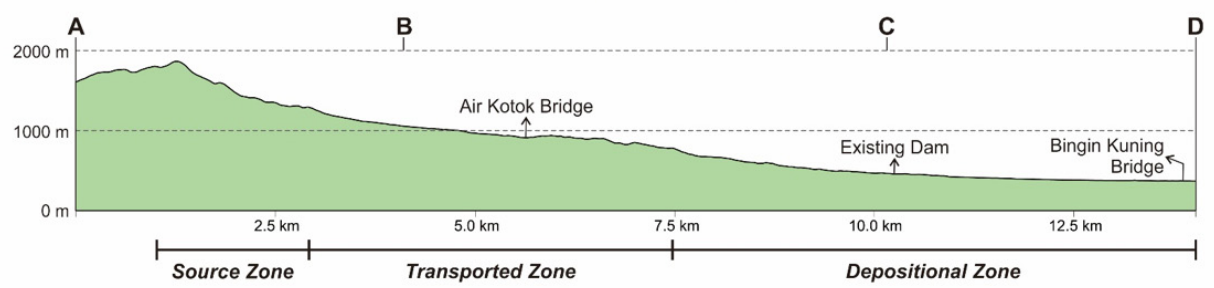

Figure 3: Beriti Hill slope gradient map and its cross-sectional profile 
appears at the mouth of a valley/stream from a mountainous region due to debris flows in non-fluvial areas [26]. Most alluvial fan areas look bare, or only covered in grass, while in other places, the areas are overgrown with tall plants/trees. Figure 2(b, c, d) show the distribution of landslide materials from Beriti Hill landslides that destroyed infrastructures, including geothermal wells and access roads.

The rocks of Beriti Hill are the rio-andesite volcano formation and the basaltic andesite volcano formation, as shown in Figure 4 [27]. The rio-andesite formation is composed of rhyolite, dacite, and andesite materials, hybrid tuff, solid tuff, volcanic breccia, and pumice of the Pleistocene age [27]. The basaltic-andesite volcanic formation has a composing lithology of andesitic-basaltic lava, volcanic breccias originating from Daun Hill. This formation is from the Pleistocene-Holocene epochs. Beriti Hill area has many geothermal manifestations around the caldera, such as fumaroles, hot springs, and steaming ground. Therefore, most soil and water in this area have acidic conditions.

Beriti Hill is part of the Bukit Barisan Mountain Range that stretches along Sumatra Island. The geological structure in Beriti Hill is influenced by a regional fault called the Semangko Fault that stretches along the island of Sumatra (NW-SE). Along the Semangko Fault Zone, several active and dormant volcanoes were found [28-29]. The geological structure in Beriti Hill shows the main directions are northwest-southeast with a relatively long dimension and northeast-west with a shorter dimension that intersects with the main structure. The Semangko Fault is a dextral fault that causes minor faults with vary- ing directions. The discontinuity structure is a weak area that reduces the carrying capacity of rocks. This weak zone is the way of hydrothermal solution from inside the earth, which accelerates the rock alteration rate. Based on the digital elevation model (DEM) image data created from LiDAR and previous data [15, 25], geological structures can be identified. The geological structure is of various directions: northeast-southwest (NE-SW), north-south (N-S), and northwest-southeast (NW-SE), as shown in Figure 4. The high geological structure density at the source areas is an indication that there are many geological structures in the area.

The Beriti Hill is prone to earthquakes because of its active sides of Sundaland in Sumatra, formed from the subduction results between the Indo-Australian Plate and the Eurasian Plate. This subduction process formed the Sumatran Fault Zone with a dextral fault type and formed an oblique pattern resulting from the tectonic strain. This subduction process also produced active faults in the same direction as the Sumatra Fault Zone, northwest-southeast. With such tectonic conditions, the study area is an active earthquake zone. The Sumatra Region Earthquake Source Map shows that the study area is close to the Musi Fault's active earthquake source, as shown in Figure 5 [30]. This fault is one of the faults located in the Sumatra Fault Zone that extends northwest-southeast. The Musi Fault has a strike-slip mechanism with a $13.5 \mathrm{~mm} /$ year slip-rate and a maximum magnitude of 7.2. In addition, the study area is also close to other earthquake sources, such as the Ketaun Fault in the north-east and the Manna Fault in the south. The two faults also have a strike-slip mechanism. The
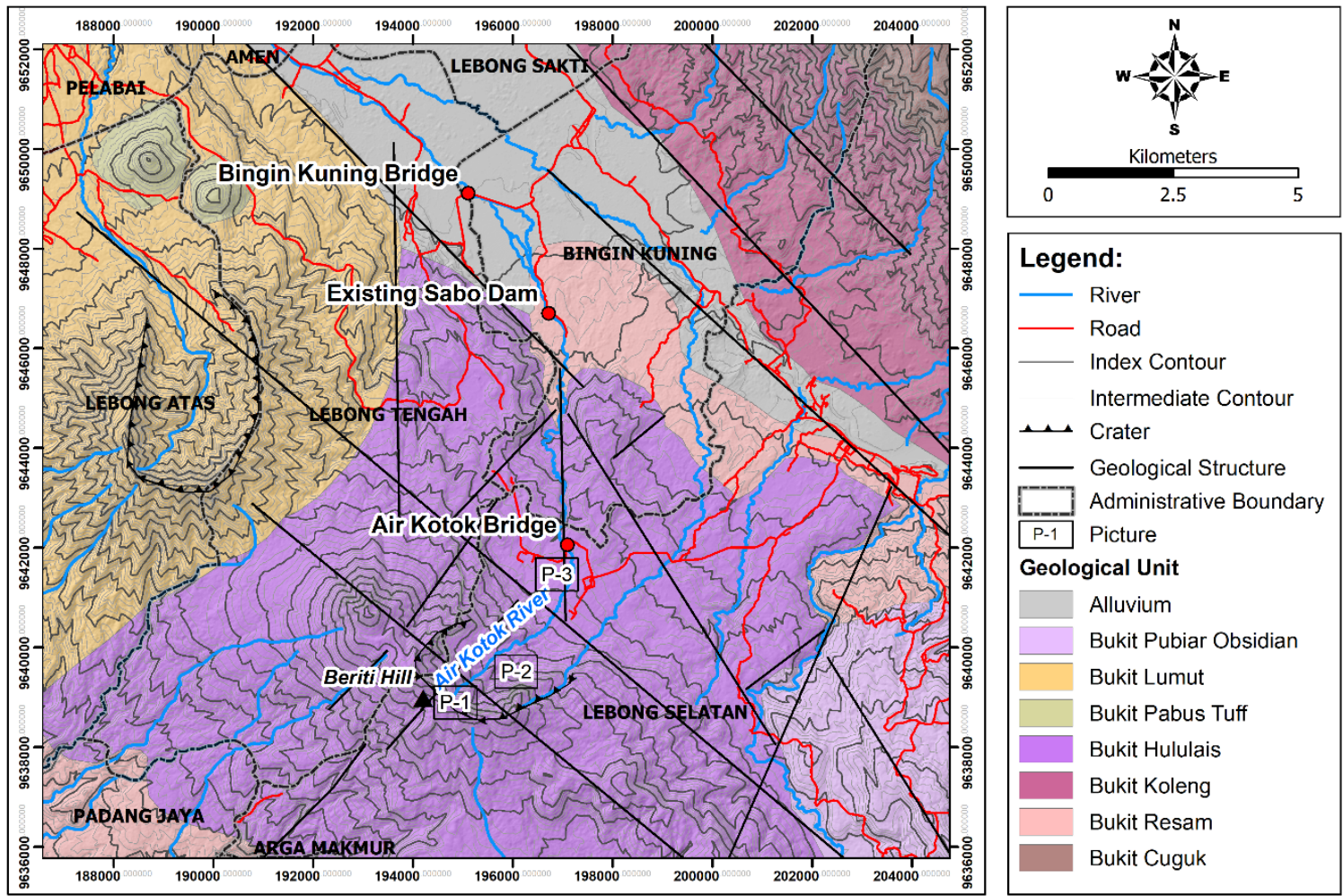

Figure 4: Geological map of Beriti Hill and its surrounding area [27] 

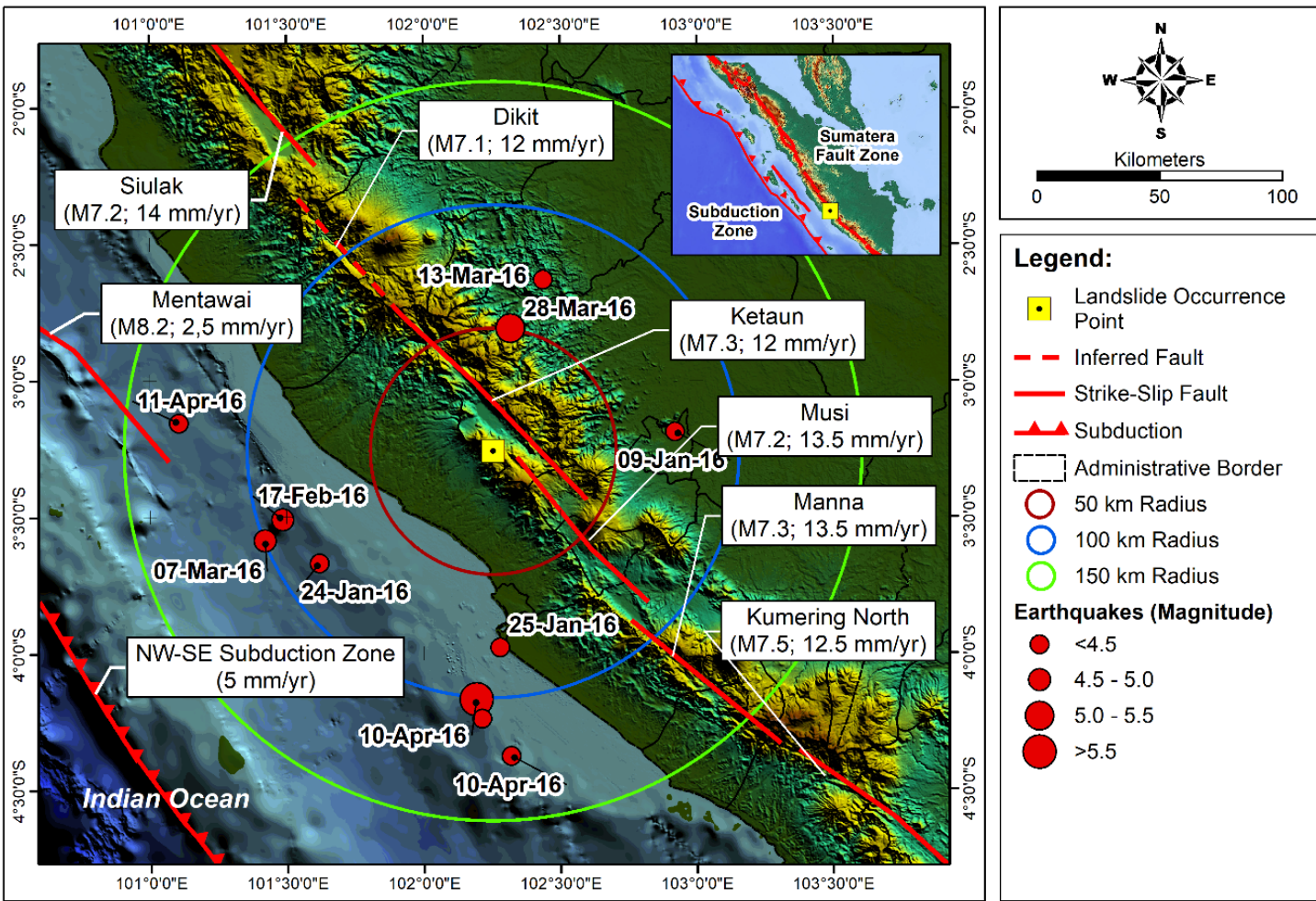

Figure 5: Map of earthquake sources and earthquake epicenters in March-April 2016 [24,30]

Ketaun fault and Manna fault have a maximum magnitude of 7.3 with a $12 \mathrm{~mm} / \mathrm{year}$ slip rate and $13.5 \mathrm{~mm} /$ year, respectively [30].

\section{RESULT AND DISCUSSION}

\section{Landslide controlling factors}

The caldera slope (source zone) comprises volcanic rocks consisting of andesite, volcanic breccia, and tuff breccia, as shown in Figure 6(a). The rocks underwent hydrothermal alterations associated directly with fumarole areas where water can accumulate or areas with low groundwater levels [15]. Table 1 shows the XRD result from the soil sample in the source, transport, and depositional zones. The source area's dominant mineral is kaolinite, cristobalite, halloysite, and trydymite, as shown in Figure 6a. Therefore, the source area has an argillic alteration [31]. The thickness of the soil layer from the alteration process is more than 10 meters. The soil has high acidity with a $\mathrm{pH}$ value of around 3.5 , while the $\mathrm{pH}$ of seepage water is 2.7. The stratigraphy of the transport zone shows the upper layer is not a well-compacted colluvial deposit followed by the intersection of andesite and andesite breccia lava, as shown in Figure 6(b). The upper and middle layers consist of chlorite, mix illite/smectite, mix chlorite/smectite, and tridymite categorized as prophylic alteration [29]. The lower layer consists of halloysite, cristobalite, quartz that indicate argillic alteration.

The headstream on the Air Kotok River cliff shows that the lowest rock in the outcrop is a volcanic breccia with a thickness of about $1.8 \mathrm{~m}$ and is indicated as a product of debris flows, as shown in Figure 6(c). The volcanic breccia matrix consists of smectite, halloysite, mix chlorite/ smectite, trydymite, and cristobalite. This clay minerals composition is similar to the material in the landslides' source zone. The middle layer is alternating sandstone and sandstone-gravel about $1.4 \mathrm{~m}$ thick, which is the river flow sediment product. The upper layer is a volcanic breccia with a thickness of about $2.8 \mathrm{~m}$.

Table 1: XRD result from each zone

\begin{tabular}{|c|c|c|}
\hline \multirow{3}{*}{$\begin{array}{c}\text { Source zone } \\
(\mathrm{P}-1)\end{array}$} & Upper & Kaolinite, cristobalite \\
\cline { 2 - 3 } & Middle & Kaolinite, cristobalite \\
\cline { 2 - 3 } & Lower & Halloysite, tridymite \\
\hline \multirow{3}{*}{$\begin{array}{c}\text { Transport zone } \\
(\mathrm{P}-2)\end{array}$} & Upper & Chlorite, Mix illite/smectite, Mix chlorite/smectite, Smectite, tridymite \\
\cline { 2 - 3 } & Middle & Mix chlorite/smectite, tridymite \\
\cline { 2 - 3 } & Lower & Halloysite, cristobalite, quartz \\
\hline \multirow{2}{*}{$\begin{array}{c}\text { Depositional } \\
\text { zone (P-3) }\end{array}$} & Upper & Halloysite, cristobalite, smectite \\
\cline { 2 - 3 } & Middle & Smectite, Mix chlorite/smectite, tridymite \\
\cline { 2 - 3 } & Lower & Smectite, Mix chlorite/smectite, critobalite \\
\hline
\end{tabular}




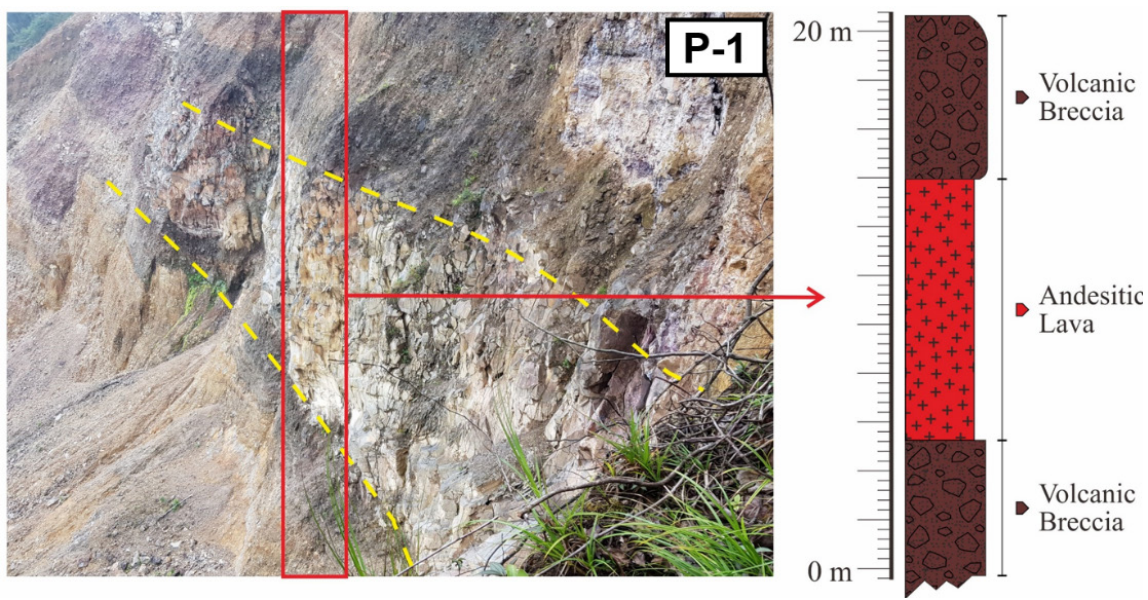

(a)

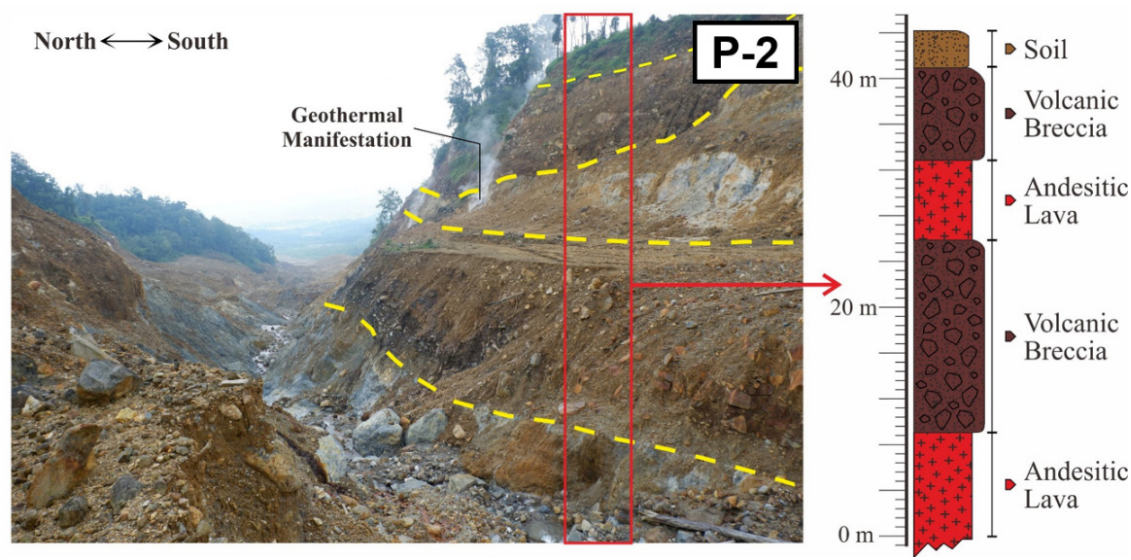

(b)

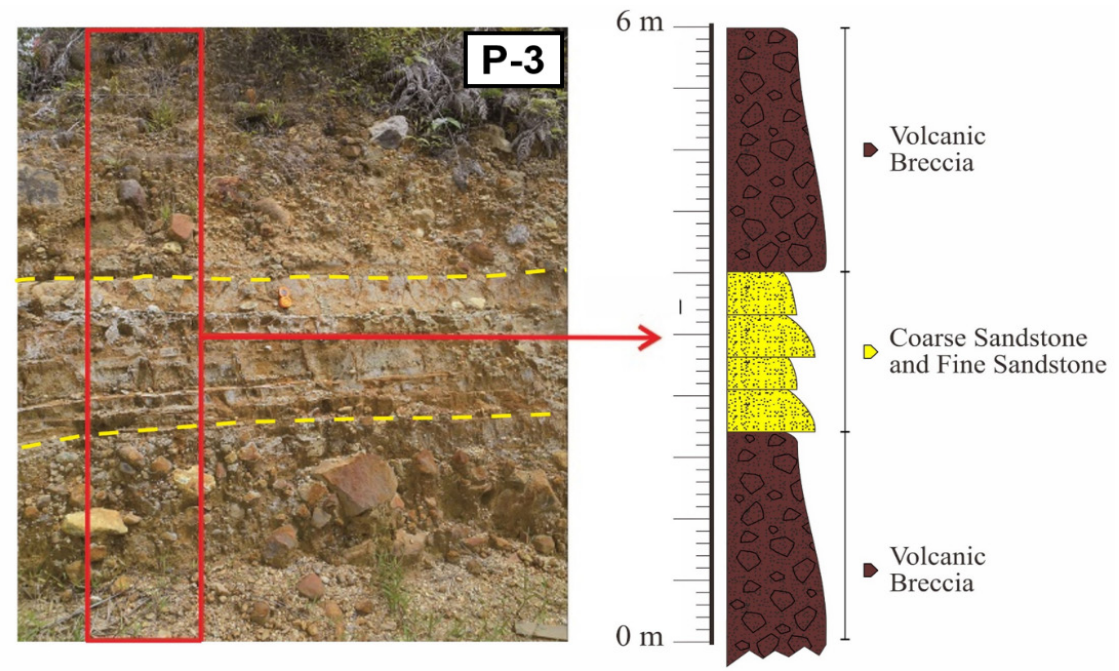

(c)

Figure 6: (a) Stratigraphy of the caldera wall of Beriti Hill (source zone), (b) Stratigraphy in the middle of the transport zone, (c) Stratigraphy on the depositional zone (the Air Kotok River cliff)

Alluvial fans are composed of lumps of rock, silty sand, and organic clay. The layer of silty sand sits above the inorganic clay layer. The thickness of the clay-sand layer varies between 1 and 4 meters. The top layer has densities from loose to solid. The cohesion obtained from the direct shear test ranges between 3 and $22 \mathrm{kPa}$. Based on the visual criteria, the inorganic silt layer can be divided into yellowish and reddish silt, $38.49 \%$ of which passed through the number 200 sieve. According to the USCS (Unified Soil Classification System), this soil is clayey sand. Furthermore, the soil has a liquid limit (LL) and plasticity index $(\mathrm{PI})$ values of $55.44 \%$ and $17.37 \%$, respectively. Based on these values, the soil can be classified as SC, clayey sand with a mixture of medium to high sand-clay plasticity. 


\section{Factors triggering landslide}

Based on the historical data on earthquakes recorded at the U.S. Geological Survey [20], the earthquake that has the most significant impact in Beriti Hill $\left(3^{\circ} 24^{\prime} 16,13^{\prime \prime}\right.$; $\left.102^{\circ} 27^{\prime} 83,14^{\prime \prime}\right)$ and its surroundings is the earthquake that occurred on April 22, 1997, with a magnitude of 5.9 Mw. The earthquakes that occurred during January-April 2016 in the study area were shallow; on April 10-11, 2016, earthquakes with a magnitude of 4-5 Mw occurred. The earthquakes' epicenter points in the study area are generally on land with a depth of $150 \mathrm{~km}$. The earthquake activity data before the landslide occurred, as shown in Figure 7. Beriti Hill has a peak ground acceleration (PGA) value of 0.6-0.8 g, referring to the peak ground acceleration map in the bedrock for a probability exceeding $10 \%$ in 50 years [30]. The PGA value is equivalent to the force/energy exposed to the building during shortterm ground shocks. An earthquake with a minimum of a horizontal ground acceleration value of 0.28 can trigger a sensitive clay layer [13]. The vibrations caused by this earthquake can trigger mass movements [32]. These vibrations cause liquefaction of slope-forming materials, especially in water-saturated material. The liquefaction process causes the land's strength and carrying capacity to decrease rapidly [33]. Water entering the material, making up the slope due to this process, can increase the slope's loading, which then triggers mass movements. Therefore, the earthquake with a high PGA value contributes to the landslide process in this area.
Generally, rainfall is one of the primary landslide triggers, especially in tropical high-precipitation regions [34-36]. Indonesia has a tropical climate with high rainfall intensity. Heavy or moderate rain that lasts a long time is very instrumental in triggering soil/rock movement. Rainwater that seeps into the soil on slopes can increase water saturation in the soil. Therefore, water pressure can stretch the bond between the soil and the soil mass transported by the slope's water flow, making the slope unstable and causing landslide or debris-flow activity. The rainfall data from the Kepahiang Meteorological Station, around 10 $\mathrm{km}$ from Beriti Hill [20], shows that the rainfall in the area of study during the landslides in April 2016 had a very high value, reaching $546 \mathrm{~mm} / \mathrm{month}$. This rainfall value is higher than the rainfall in the previous months, which ranged from $200-300 \mathrm{~mm} / \mathrm{month}$. Besides, detailed data from JAXA Global Rainfall Watch [21] shows the rainfall in Beriti Hill on the day before the landslide occurred reached $58.41 \mathrm{~mm} /$ day, and at the time of the incident, it was $46.51 \mathrm{~mm} /$ day, as shown in Figure 7 . Then, subsequent landslides occurred on April 30, May 2, and May 3 , during which rainfalls were $20.93,52.71$, and 20.81 $\mathrm{mm} /$ day. Heavy rain causes the rocks on Beriti Hill to be more unstable and easy to move for landslides. A landslide can be transformed become debris flow due to heavy continuous rainfall in the mudstone-sandstone mixed stratum [14].

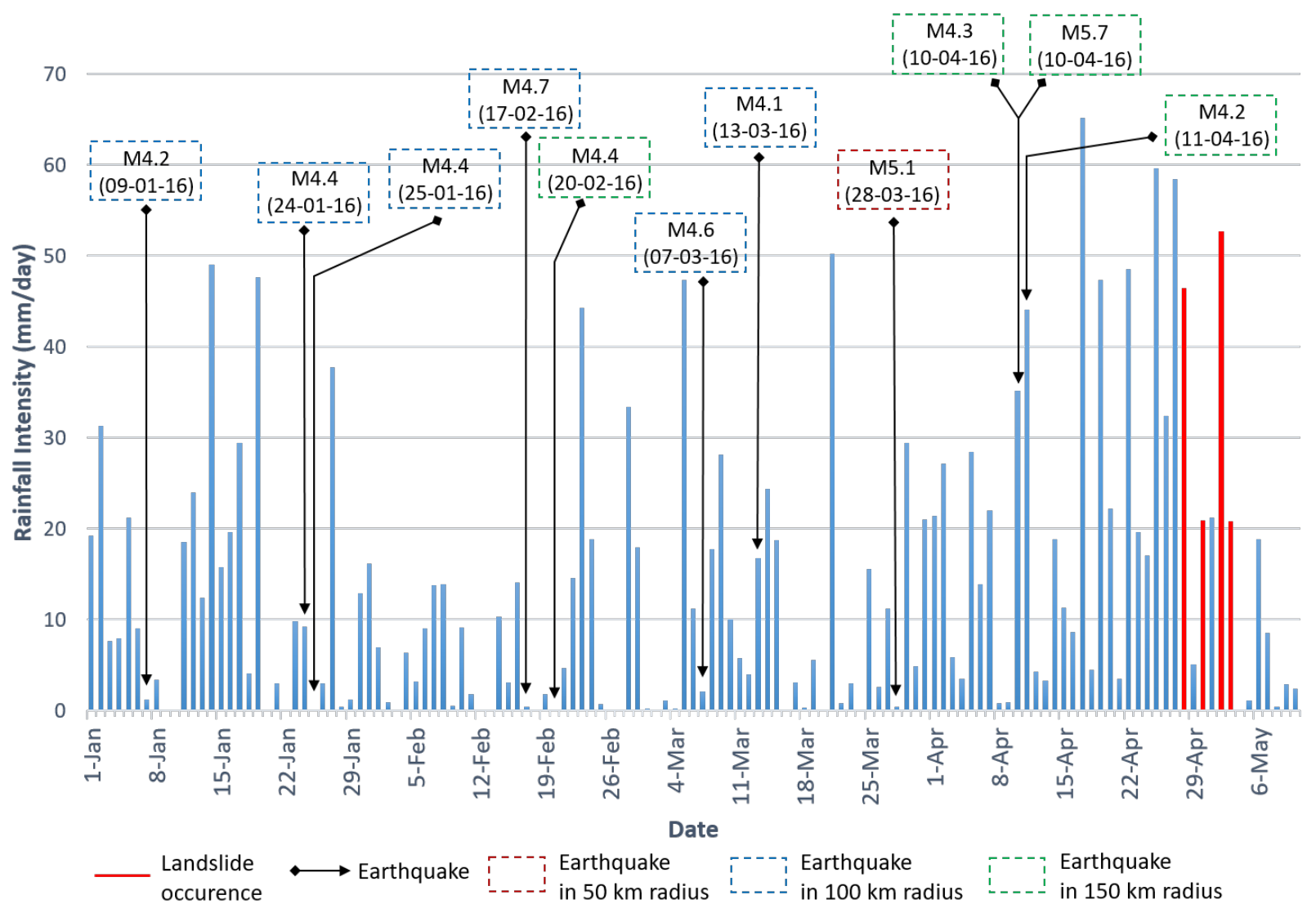

Figure 7: Daily rainfall and significant earthquake from January to May 2016 at Beriti Hill [23, 24] 


\section{Discussion}

The wall slope of Beriti Hill caldera as a source area has a steep slope of more than $40^{\circ}$. With the steepness of this slope, the site is very vulnerable to landslides. This caldera has a gap in the north-east part that forms a narrow and steep valley. Northeastward, the slope is less steep upstream of the Air Kotok river. There is alluvial fan sediment morphology at the end of the slope. The characteristics of rocks around the caldera that experienced intensive geological structures caused the hydrothermal solution to flow upwards through the weak zone. This hydrothermal process is marked by fumaroles and hot springs, which resulted in rock alteration and produced very thick soil deposits accompanied by rock chunks. The sliding surface of the landslide consisted of clay minerals such as halloysite, cristoballite, and quartz. The weathering or alteration process will also reduce the soil/rock slope's strength, causing landslides, especially during heavy rains [37-39].

An earthquake occurring within a $50 \mathrm{~km}$ radius on March 28,2016 , with a magnitude of 5.1 on the Richter scale and three successive earthquakes on April 10-14, 2020, did not trigger immediate landslides, as shown in Figure 7. It indicates the effect of earthquakes on landslides in Beriti Hill is lower compared to that of rainfall.

A landslide occurred on April 28, 2020, with daily rainfall reaching $46.51 \mathrm{~mm} /$ day, lower than April 17, which reached $65.19 \mathrm{~mm} /$ day. It shows that the occurrence of landslides is not triggered by daily rainfall but is more influenced by antecedent rainfall. Most landslides are triggered by 10 -day rain with total rainfall of more than $88.35 \mathrm{~mm}$ [40], while the rainfall in Beriti Hill in the last ten days before the landslide reached $355.21 \mathrm{~mm}$. Previous research also supported that more than $61 \mathrm{~mm}$ a day or three-day rain with a cumulative intensity of more than $91 \mathrm{~mm}$ will trigger landslides in Indonesia [41].

Continuous rain caused some water to be retained at the top of the hill and formed high saturation in the soil, causing infiltration where water entered soil pores to the point of contact with the bedrock. When the load on the slope increased, the slope's stability was disrupted, and a landslide occurred. Landslide material in the form of andesite boulder fragments and weathered volcanic breccias material slid down along the $2.5 \mathrm{~km}$ and damaged the geothermal facilities. The movement of material from the caldera wall also eroded the cliff wall of the valley passed by, so it produced deeper valleys upstream, adding to the landslide material as shown in Figure 6(b). The debris flow slides' material volume reached 4,300,000 $\mathrm{m}^{3}$ based on topographic contour maps from LiDAR before and after the landslide. The debris flow material buried all agricultural areas downstream, as shown in Figure 2(a). The material had a high acidity that makes all the vegetation dead. It takes a long time to make the $\mathrm{pH}$ of the soil neutral. Therefore, it is necessary to put topsoil from other areas with high fertility for the reforestation process or add lime in the debris materials to increase the $\mathrm{pH}$. Dense vegetation is essential to minimize debris flow impact distribution in the future of landslides, especially the transported zone.

Landslides-induced debris flow in Beriti Hill and surrounding areas are recurring events. The Air Kotok River's stratigraphic data shows evidence of this process that consists of a repetition of volcanic rock breccia layers with sandstones, as shown in Figure 6(c). In debris flow events, large material (volcanic breccia materials) will be deposited, while sand materials will be deposited under normal conditions. Also, Google Earth photos show an alluvial fan in the Air Kotok River channel's slope in the bend section. Grass dominates the alluvial fan sedimentation area, which differs from other places, as shown in Figure 2.(a). It shows that this area was once buried by landslide materials, which caused large plants/perennials to die/disappear. The current distribution of debris-flow deposits in the alluvial fan shows the same pattern as before, as shown in Figure 2.(a)

\section{CONCLUSIONS}

The geothermal area is prone to landslides since the alteration process produces a thick soil layer dominated by clay minerals. Besides, most of the geothermal areas are located in mountainous areas with steep slopes, dense geological structures, and high rainfall intensity. The landslide in Beriti Hill occurred due to the collapse of the mass block of soil and rock, controlled by the thick soil layer conditions due to the alteration process, and supported by steep slopes (more than $40^{\circ}$ ). The landslide occurred after prolonged rain, not soon after an earthquake. It seems that antecedent rainfall has more contributed than the earthquake to trigger the landslide in Beriti Hill. The cumulative rain was occurring within ten days before the landslide is $355.21 \mathrm{~mm}$. Landslides were recurring events based on the Air Kotok River wall's stratigraphic records and the alluvial fan deposits' morphology downstream. Therefore, the Air Kotok River area, especially the alluvial fan deposit, is a debris flow hazard area and is not suitable for a residential area and agriculture. The debris flow material is toxic for vegetation due to its acidity. It is necessary to build a dam in the transported zone and increase the Air Kotok River's volume to mitigate the landslide in the future. Besides, it needs installing early-warning sensors around Beriti Hill caldera to monitor soil/rock movement, including rain gauge, extensometer, and tiltmeter.

\section{ACKNOWLEDGMENTS}

We would like to thanks PT. Pertamina Geothermal Energy (PGE) for their funding during field investigation. We also thank Egy Erzagian, Thema Arrisaldi, and Anissa Nur Amalina from Gama-InaTek for their support during fieldwork. 


\section{REFERENCES}

1. Cruden, D.M. and Varnes, D.J. (1996). Landslide Types and Processes. In: Turner, A.K. and Shuster, R.L., Eds., Landslides: Investigation and Mitigation, Transportation Research Board, Special Report No. 247: 36-75.

2. Varnes, D.J. (1978). Slope movement types and processes. In: Schuster, R.L., Krizek, R.J. (Eds). Special Report 176: Landslide: Analysis and Control. Transportation Research Board, National Academy of Sciences, Washington DC.

3. Li, Y. and Mo, P. (2019). A unified landslide classification system for loes slopes: A critical review, Gemoprhology, Vol. 340, 67-83, DOI: 10.1016/j.geomorph.2019.04.020

4. Yin, Y., Cheng, Y., Liang, J., Wang, W. (2016). Heavy-rainfall-induced catastrophic rockslide debris flow at Sanxicun, Dujiangyan, after the Wenchuan Ms 8.0 earthquake. Landslides, Vol. 13, No. 1, 9-23, DOI: 10.1007/s10346-015-0554-9

5. Wang, Y., Zhao, B. and Li, J. (2018). Mechanism of the catastrophic June 2017 landslide at Xinmo Village, Songping River, Sichuan. Landslides, Vol. 15, No. 2, 333-345, DOI: 10.1007/s10346-017-0927-3

6. Drempetic, V., Morles, M.S. and Merodo, J.A.F. (2015). Depth Averaged Models for Fast Landslide Propagation: Mathematical, Rheological, and Numerical Aspects. Arch Computat Methods Eng, Vol. 22, 67-201, DOI: 10.1007/s11831-014-9110-3

7. Skilodimou, H.D., Bathrellos, G.D., Koskeridou, E., Soukis, K. and Rozos, D. (2018). Physical and Anthropogenic Factors Related to Landslide Activity in Nothern Peloponnese, Greece. Land, Vol. 7, No. 85, 1-18, DOI: 10.3390/land7030085

8. Glade, T. and Crozier, M.J. (2012). The Nature of Landslide Hazard Impact. Glade T, Anderson M, Crozier M.J. (Eds.), Landslide Hazard and Risk, John Wiley \& Sons Ltd, USA, p. 41-74. DOI: 10.1002/9780470012659.ch2

9. Hidalgo, C.A. and Alexánder, J.A. (2014). Hazard estimation for landslide triggered by earthquake and rainfall (Aburra Valley-Colombia). Revista EIA, Vol. 22, 93-107, DOI: 10.14508/reia.2014.11.22.103-117

10. Clark, K.E., West, A.J., Hilton, R.G., Asner, G.P., Quesada, C.A., Silman, M.R., Saatchi, S.S., Rios, W.F., Martin, R.E., Horwath, A.B., Halladay ,K., New, M., Malhi, Y. (2016). Storm-triggered landslides in the Peruvian Andes and implications for topography, carbon cycles, and biodiversity. Earth Surface Dynamics, Vol. 4, No. 1, 47-70, DOI: 10.5194/esurf-4-47-2016
11. Saito, H., Uchiyama, S., Hayakawa, Y.S., Obanawa, H. (2018). Landslides triggered by an earthquake and heavy rainfalls at Aso Volcano, Japan, detected by UAS dan SfM-MVS photogrammetry. Progress in Earth and Planetary Science, Vol. 5, No. 15, 1-10, DOI: 10.1186/s40645-018-0169-6

12. Conforti, M. and letto, F. (2020). Influence of tectonics and morphometric features on the landslide distribution: a case study from the Mesima Basin (Calabria, South Italy). J Earth Sci, Vol. 31, No. 2, 393-409, DOI: 10.1007/s12583-019-1231-z

13. Wang, B. (2019). Failure mechanism of an ancient sensitive clay landslide in eastern Canada. Landslide, Vol. 16, 1483-1495, DOI: 10.1007/s10346019-01198-4

14. Chen, X.Z. and Cui, Y.F. (2017). The Formation of the Wulipo Landslide and the Resulting debris flow in Dujiangyan City, China. Journal of Mountain Science, Vol. 14, No. 6, 1100-1112, DOI: 10.1007/ s11629-017-4392-1

15. Kamah, M.Y., Palmelay, A.C., Rahardjo, I.B., Thamrin, M.H., Hartanto, D.B., Silaban, M.S., Sasradipoera, S.D. (2015). Successful Exploration Campaign and to be Developed in Hululais Geothermal Field, Bengkulu Indonesia, Proceedings World Geothermal Congress 2015, p.1-5.

16. Shirahata, H., Asahi, H. and Oura, H. (1987). Relationship between Rock Alteration and Landslides in the Noboribetsu District, Southwest Hokkaido. Journal of the Japan Society of Engineering Geology, Vol. 28, No. 2, 47-53, DOI: 10.5110/jjseg.28.47

17. Winarti, D., Karnawati, D., Hardiyatmo, H.C., Srijono (2016). Mineralogical and Geochemical control of altered andesitic tuff upon debris slide occurrences at Pelangan area, Southern Mountain of Lombok Island, Indonesia. Journal Applied Geology, Vol. 1, No. 1, 19 - 28, DOI: 10.22146/jag.26953

18. Putra, I.D., Titisari, A.D., Husna, H.Z.K. (2019). Clay Mineralogy of Landslide occurrences in hydrothermally altered area: A case study of Durensari area, Purworejo, Central Java. E3S Web Conferences 76, 02008. DOI: 10.1051/e3sconf/20197602008

19. Google earth pro, accessed on 15 August 2019.

20. Moore, D.M. and Reynold, R.C. (1997). X-Ray Diffraction and the Identification and Analysis of Clay Mineral, 2nd, Oxford University Press, Oxford.

21. Volker, D.J. (2010). A simple and efficient GIS tool for volume calculations of submarine landslide. Geo-Marine Letter, Vol. 30, 541-547, DOI: 10.1007/ s00367-009-0176-0. 
22. Meteorology, Climatology and Geophysics Agency of Indonesia (BMKG) (2017). Rainfall Data Report of Rejang Lebong District, Bengkulu Province, Indonesia.

23. Earth Observation Research Center (EORC), Japan Aerospace Exploration Agency (JAXA). JAXA Global Rainfall Watch (GSMaP NRT), http://sharaku.eorc. jaxa.jp/GSMaP/index_e.htm, Accessed on 25 July 2019.

24. U.S. Geological Survey (USGS): http://earthquake. usgs.gov/earthquakes/search/, Accessed on 2 July 2019.

25. Conforti, M. and letto, F. (2019). An integrated approach to investigate slope instability affecting infrastructures. Bull Eng Geol Environ, Vol. 78, No. 4, 2355-2375, DOI: 10.1007/s10064-018-1311-9.

26. Harvey, A. (2011). Dryland alluvial fans. In D. S. G. Thomas (Ed.), Arid zone geomorphology: Process, form and change in drylands 3rd ed., p. 333-371. DOI: $10.1002 / 9780470710777 . c h 14$

27. Gafoer, S., Amin, T.C., Pardede, T. (1992). Geological Map of Bengkulu Sheet, Geologycal Agency of Indonesia, Bandung, Indonesia.

28. Barbera, J., Crowm, J., Milsomj, S. (2005). Sumatra: Geology, Resources and Tectonics. Geological Society Memoir 31. Geological Society of London, London. DOI: 10.1144/GSL.MEM.2005.031

29. Hakam, A. and Istijono, B. (2016). West Sumatra landslide during in 2012 to 2015. International Journal of Earth Sciences and Engineering, Vol. 9, No. 3, 289-293.

30. Ministry of Public Works and Public Housing of The Republic of Indonesia. (2017) Map of the source and hazard of the earthquake in Indonesia 2017.

31. Corbett, G.J. and Leach, T.M. (1998). Southwest Pacific rim gold-copper systems: Structure, alteration and mineralization: Economic Geology, Special Publication 6, Society of Economic Geologists. DOI: 10.5382/SP.06

32. Nakamura, S., Wakai, A., Umemura, J., Sugimoto, H., Takeshi, T. (2014). Earthquake-induced landslide: distribution, motion and mechanisms. Soils and Foundation, Vol. 54, No. 4, 544-559, DOI: 10.1016/j. sandf.2014.06.001

33. Idriss, I.M. and Boulanger, R.W. (2008). Soil Liquefaction During Earthquakes, Earthquake Engineering Research Institute, USA.
34. Peruccacci, S., Brunetti, M.S., Luciani, S., Vennari, C., Guzzetti, F. (2012). Lithological and seasonal control on rainfall thresholds for the possible initiation of landslides in central Italy. Geomorphology, Vol. 139, No. 140, 79-90, DOI: 10.1016/j.geomorph.2011.10.005

35. Yang, Z., Lan, H., Liu, H., Jiang, Li, L., Wu, Y., Meng, Y., and Xu, L. (2015). Post-earthquake rainfall-triggered slope stability analysis in the Lushan Area. Journal of Mountain Science,Vol. 12, No. 1, 232-242, DOI: 10.1007/s11629-013-2839-6

36. Haque, U., Silva, P.F.D., Devoli, G., Pilz, J., Zhao, B., Khaloua, A., Wilopo, W., Andersen, P., Lu, P., Lee, J., Yamamoto, T., Keellings, D., Hong, W.J., Glass, G.E. (2019). The human cost of global warming: deadly landslides and their triggers (1995-2014). Science of the Total Environment, Vol. 682, 673-684, DOI: 10.1016/j.scitotenv.2019.03.415

37. Pioquinto, W.P.C., Caranto, J.A., Bayrante, L.F., Zarco, M.H., Catane, S.G. (2010). Mitigating a Deep-Seated Landslide Hazard- the Case of 105 Mahiao Slide Area, Leyte Geothermal Production Field, Philippines. Proceedings World Geothermal Congress 2010, p. 1-7.

38. Frolova, J., Ladygin, V., Rychagov, S., Zukhubaya, D. (2014). Effects of hydrothermal alterations on physical and mechanical properties of rocks in the Kuril-Kamchatka island arc. Engineering Geology, Vol. 183, 80-95, DOI: 10.1016/j.enggeo.2014.10.011

39. Wijaya, I.P.K, Zangel, C., Straka, W. and Ottner, F. (2017). Geological Aspect of Landslide in Volcanic Rocks in a Geothermal Area (Kamojang Indonesia) in Mikos M, Vilimek V, Yin Y, Sassa K (eds) Advancing Culture of Living with Landslides. Springer, World Landslide Forum 5, p. 429-437. DOI: 10.1007/978-3319-53483-1_51

40. Dikshit, A., Sarkar, R., Pradhan, B., Acharya, S., Dorji, K. (2019). Estimating Rainfall Thresholds for Landslide Occurrence in the Bhutan Himalayas. Water, Vol. 2019, No. 11, 1616, DOI: 10.3390/w11081616

41. Hidayat, R., Sutanto, S.J., Hidayah, A., Ridwan, B., Mulyana, A. (2019). Development of landslide Early Warning System in Indonesia. Geoscience, Vol. 2019, No. 9, 451, DOI: 10.3390/geosciences9100451

Paper submitted: 06.12.2020.

Paper accepted: 19.03.2021.

This is an open access article distributed under the CC BY 4.0 terms and conditions.

Istraživanja i projektovanja za privredu ISSN 1451-4117 Journal of Applied Engineering Science Vol. 19, No. 3, 2021 